\title{
Jurgen Moltmann's Theology of Hope and the Task of Public Theology in Ghanaian Context
}

\author{
Francis Appiah-Kubi \& Isaac Osei Karikari ${ }^{1}$ \\ ${ }^{1}$ Department of Religious Studies, Kwame Nkrumah University of Science and Technology, Kumasi-Ghana.
}

\begin{abstract}
This article examines the relevance of theology in public life particularly from the Ghanaian (African) Christian experience in society. The idea of the public relevance of theology has been ably examined by Jurgen Moltmann in the perspectives of his Theology of Hope and the continuous reflections in the "Ethics of Hope". The eschatological sacrifice of Christ's story animates in Moltmann the understanding of what particular transformation one must experience when envisaging what the shape of Christianity is in modern society and the task it has to fulfill in the field of social ethics in the Ghanaian social and political history. Critical to the Ghanaian social-political life is to be encountered with is a sub-culture trend that the task for the socio-political and the economic development of the nation-state is the preserve of politics or political activists. The conversation on the rise to action of the Ghanaian Christian to social ethics is now due to the growing trends of poverty, violence, unemployment, corruption, dwindling social and moral order and failing institutions of state. Jurgen Moltmann develops his thoughts in the Ethics of Hope to deliberately project Christian social ethics that is focused on projecting the Bible as the gospel of hope for the people. This paper evaluates Moltmann's understanding of modern realities of life and how Christians must relate with and what Christian character brings to bear on the positive change in the life of the people.
\end{abstract}

Keywords: Public Theology; Political theology; modernity; Social ethics; social context.

\author{
Correspondence \\ Isaac Osei Karikari \\ Email: oseikark@gmail.com \\ Publication History \\ Received 19th June 2020, \\ Accepted 31st August 2020, \\ Published online 22nd September \\ 2020.
}

\section{INTRODUCTION}

Jurgen Moltmann is a foremost theologian and professor of Systematic Theology who is still alive at age 90 and has been dreaming of developing his understanding of what could be developed as Christian Ethics from Christian Theology or Doctrine. Moltmann has always been enthused by the idea of theology developing from a particular context, Christian or other Religion rather than from a philosophical extrapolation. He believes that theology must be developed from contextual (Existential) realities. Moltmann's understanding of the idea of Christian Ethics has been developed in his Ethics of Hope. ${ }^{2}$ Christian ethics emerging from Christian theology for Moltmann must not only be what determines the way of life of a people but what social context Christian theology must participate to transform the human realities in the future of the Christ's experience. So in this article, the journey through contextual theological reflection is prominent in the equation. Moltmann has attempted to offer a way of doing theology that is culturally new and at the same time rooted in scripture and tradition. ${ }^{3}$

He has maintained throughout the evolution of his thought that Christian theology has the obligation to remain open to the world and be responsive for the ethical demands made of it by its social situation. Moltmann's view in respect of the project of theological reflections done contextually has been buttressed by Stephen Bevans; hence contextual theology is a theology that, in addition to recognizing the roles of scripture and tradition, also recognizes the dimensions of culture, history, contemporary ways of thought and human experiences in shaping the context in which theological

Jurgen Moltmann, Theology of Hope, On the Ground and Implications of a Christian Eschatology (New York: Harper and Row, 1967), 25.

Stephen Bevans, Models of Contextual Theology (Maryknoll: Orbis Books, 2002), 27. 
reflection and action take place. ${ }^{4}$ In fact, Bevans and Moltmann all agree with the reality that as finite human creatures struggling to grasp the infinite (that is God), humans can only do that through their own life subjective interpretive lenses.

Moltmann admits to the fact that his theological project would have to undergo reflective changes after the development of the Theology of Hope in 1968 which had a context to deal with at the time. He together with J. B. Metz pitched camp with the intellectual idea of what he referred to as 'political theology'. This concept of political theology was meant to provoke theology unto its social relevance and become socially engaged with the deepest commitment of the state to the needs of the citizen. In view of this, he developed the Ethics of Hope which to him was intended to be based on Christian ethics within the framework of the Christian experience and history nuanced in the eschatological realities of the Christ's event. Thus for Moltmann, Christians have the opportunity to make suggestions for action in all human endeavors with hope in the future of the Christ, "this ethics is related to the ethos which has to do with endangered life, the threatened earth and the lack of justice and righteousness. It is not a discussion of timeless general principles; but in the face of these dangers, it focuses on what has to be done today and tomorrow with the courage of hope", Moltmann asserts. $^{5}$

This article reflects on the African (Ghanaian) experience of the Christ beyond the transformation that is from spiritual Koinonia but towards a social realist point of departure. So to be on the side of Moltmann, as he attempts to answer the question of Immanuel Kant; "What can I hope for" in his "Ethics of Hope". This affects the various choices of action open to all in response to the question of massive youth unemployment, rapacious socio-economic and political lifestyles, down-sliding cultural and human values, and economic downturns, uncertain health care system (National Health Insurance System-NHIS) environmental-ecological disintegrations. Besides, what do all these mean to religion, or theology, particularly from Christian perspective and spirituality, with God and with the new trends in Christian spiritual aspirations. The crux of the matter is that, God entrusts mankind with the measure of responsibility for the sustainability of material and natural resources. For Emmanuel Asante, it is a call for genuine ministry which is guided by God's character and leads to the preservation of the wholeness of the needs of human beings. ${ }^{6}$

\section{MOLTMANN, MODERNITY AND AFRICAN RATIONALITY}

The study examines how theology will engage civil society in the reality of consciousness towards modern ways of living; secularization, plurality in institutional life and functions and the new trends in the democratization of all social obligations. The fundamental issues will be the understanding of modernity from African experience and how Moltmann understands modernity and the points of convergence or contacts with the Africans' perspectival motif of the modern reality of things. Moltmann often speaks of his theology as being experimental, open to adjustment and revision when faced with context-specific ethical conundrums.

For him theology is an adventure of ideas, an inviting path on which "the road emerged only when as I walked it". ${ }^{\prime}$ Richard Buackham reflecting on Moltmann's realistic attitude to modern trends in socio-political life has emphasized that, "for Moltmann, Christian political engagement is no substitute for Christian faith, but one of the forms which faith must take in action..." ${ }^{8}$ This is to emphasize that Moltmann has developed his theology to remain responsive to that political (Social) function concerning how the church views its own public responsibility. ${ }^{9}$

Modernity refers to the movement of ideas, practices and institutions that originated in Europe the roots of which are generally traced to the Renaissance, moving through the voyages of Discovery, the Reformation and the Enlightenment. It gave such milestones as the English Civil War and Act of Settlement of 1701, the American Revolution, the French Revolution, the Haitian Revolution, the Scientific Revolution, the Industrial Revolution, as well as Capitalism. But, it is modernity's philosophical discourse that interests us because, ultimately, its most lasting impact has not been that it enabled us to build nuclear weapons or send humans into space. ${ }^{10}$

The study examines in detail the concept of secularization or a critique of it in this work. However some basic understanding will help. Secularization has been one of the most predominant characterizations of modernity in all aspects of human life. Jose Casanova has reiterated his point that, secularization as a concept is a historical process which has challenged the dualistic system of "this world" and the sacramental structures of mediation between this world and the other world to break down. ${ }^{11}$

\footnotetext{
Duncan Forester, The Scope of Public theology, (New York: The Continuum Publishing Group, 2004), 37.

Moltmann, Ethics of Hope, 2012, Preface, xii,

Emmanuel Asante, Theology and Society in Context, (Accra: Sonlife, 2014), 9.

Jurgen Moltmann, Experiences in Theology (Philadelphia: Fortress Press, 2000), xv.

Richard Bauckham, The Theology of Jurgen Moltmann, (Edinburgh: T \&T Clark, 1999), 99.

Duncan Forrester, The Scope of Public theology, 36.

10 Olufemi Taiwo, 'Africa and her Challenge of Modernity', Visiting Professor of Philosophy, University of West Indies, Mona Campus, Kingston, Jamaica and Department of Philosophy, Seattle University, U. S. A, 3.

11 Jose Casanova, Public Religions in a Modern World, (Chicago: University of Chicago Press, 1994), 15.
} 
The wall separating the religious and the secular realms within "this world" breaks down. Casanova believes that the order of the day is that, there is only one single world-the secular- within which religion will have to find its own place. He puts it so succinctly this way; "if before, it was the religious realm which appeared to be all encompassing reality within which the secular realm found its proper place, now the secular sphere will be the all-encompassing reality to which the religious sphere will have to adapt." ${ }^{2}$

It used to be the case that modern trends or phenomena were Western oriented or Europeanized experience, but now it is an African challenge. The South African experience of modernity and its challenge on religion or on Christianity in particular cannot be underrated. Smit puts it in this brief analysis. There are two perspectives that he looks at; the relationship between the Reformed faith, tradition and theology on one hand with its typical political, economic, social and cultural institutionalizations on the other hand. This itself has always been extremely ambiguous. The second observation by Smit is that it is difficult to understand a shift in South African societies. According to him, on the one hand, it is most certainly the radical and rapid institutionalization of modernity. On the other hand in less than a decade, South African society is undergoing dramatic institutional change that sometimes would take more than two centuries in other countries. ${ }^{13}$

Though modernity has been accepted as a development paradigm in many socio-cultural and economic environments, Smit describes its phenomenon as in crisis. This is why Moltmann in most of his works proposes a paradigm shift in developing appropriate theological responses to deal with the ethical conundrums associated with the modernization of the social order.

The movements in modern trends have walked Moltmann into placing his theological thoughts in the context of the growing consciousness of economic and technological advancements and their impact on the social life of particular people. This is how Moltmann describes modernity;

Modern society is a child of industrial revolution. Today societies are in fact going through the third industrial revolution: the mechanization of production was followed by its electrification, and nowadays we have computerization. The change in methods of production demands mobility and flexibility from the men and women concerned. It requires of them the ability to realize new potentialities and the strength to overcome the contradictions and the conflicts they suffer in the process. Socially and politically, modern industrial society is inevitably a society of permanent reform. ${ }^{14}$

For him the thirst for economic and technological advancements as key phenomena of modernity is only a response to the consciousness of the hope for a better future, and also as he has stated; "we become aware of the future not only in our hopes for better times in the future but also, if not even for the most part, in our fears and anxieties ... we are worried by the possibility of all the things that can happen. Fear and anxiety are early warning systems of possible dangers and are necessary for human living." 15 There is a need to strive to catch up with advancement in whatever form it takes so that mankind is not left behind.

African's understanding of the idea of the positivity in hope connects with Moltmann's theological consciousness of hope and human existence. For Moltmann, the hope for the future without hope in God's future and the ethical responsiveness to God's expectation of the future has no foundational basis. In other words, God through Christ establishes the human consciousness of eschatological life realism. The real experience is that, the death and the suffering of Christ represent the current suffering and pains of humanity and the resurrection is a pointer to a life that has hope not static and moving forward.

For Moltmann, in reflecting on the experience of the risen Christ in the transformed life of the people, Christian ethics of hope is called to life and therefore expects the dawn of the new world of God in the passing of the old world. ${ }^{16}$ Moltmann grounds his social ethics on the Christian hope which according to him is founded on Christ's resurrection and opens up a life in the light of God's new world. Christian ethics anticipates the universal coming of God in the potentialities of history. ${ }^{17}$

In this part of the world as Africans, particularly in the Ghanaian context, the future is in 'the hands' of God. There are popular sages and proverbs that emphasize the human dependence on God to determine what one desires to achieve looking into the future. One such popular sage in the Twi dialect is; "Se wodo afuo na Onyankopon anhu mu a, enye yie" (if you cultivate your farm and God does not look into it, there will be no meaningful results or harvests). The belief that God 'falls' rain on one's farm for it to be fruitful is imbedded in the ethical consciousness towards God and the desire to see a fruitful future. So for the African, modernity is all about growth, transformation and development into a better future. However, modernity which gives birth to development presents a complexity in the African way of perceiving it.

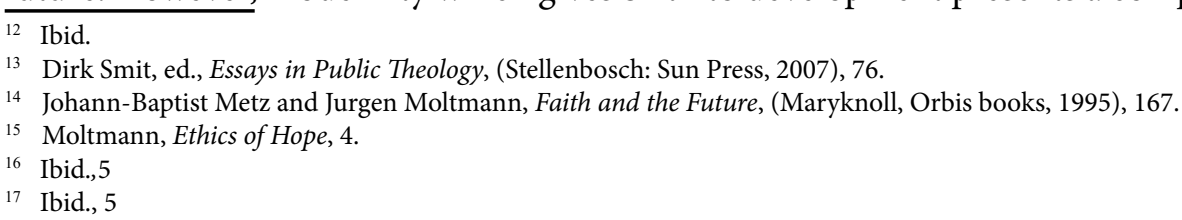


For Kwame Gyekye, this complexity "calls for a comprehensive, not segmented approach to the development of human society and culture." Gyekye, perceives in terms of adequate responses to the entire existential conditions in which human beings' function, conditions which encompass the economic, political, social, moral, cultural, intellectual and others" ${ }^{18}$ In the experience of modernity, the condition that must be fulfilled calls for what Gyekye has established as; "a congenial political, viable ethical and cultural framework." ${ }^{19}$

The framework within which any human entity can develop is what Moltmann believes theology must engage, being in a moment of showing the love of God to humanity. Moltmann asserts that, human life today is in acute danger, but not in the essence of life being threatened with death, but it is in acute danger because life is no longer loved.The challenge of modernity to the African socio-cultural and politico-economic life cannot escape the theological and ethical lenses of Moltmann. Though in all his writings the context has been European specific, but the relevance of his thought in the current work of the Ethics of Hope and the others give hope of a universal relevance to the issues he has discussed. Modernity according to Moltmann has produced what he describes as the 'terror of death' to human life. He asserts that if that trend in the pretext and under the guise of modernity; development, technology and economic emancipation continues then the question is does modern society have a future? ${ }^{20} \mathrm{He}$ poses the question not because (as he puts it), he is being pessimistic but optimistic which is based on responsible realism.

There will be no need for a benevolent or doom prophet to tell any group of people what the uncritical acceptance of everything modern is, particularly in African life and culture is. Moltmann cites a number of issues that modernity has brought to the changing world. First of all he looks at the issues of religious fundamentalism emerging from some parts of the world and its effects on human existence. "Today we are experiencing a new and frightening 'religion of death' Your young people love life; our young people love death.21 This was a comment made by the Taliban leader Mullar Omar after the bomb explosion in a Madrid train in March 11, 2004. This is a threat to the Western world and the rest of the world. Moltmann also shares his views on the modern trends of the decline into social destitution, the life of the people particularly in the African part of the world. Moltmann contends that;

For more than forty years, the world has been hearing the lamentation on every side the gap between the rich and the poor getting wider and wider. A small wealthy upper class dominating the masses of impoverished people, which is not just a problem of the third world but even in the democracies of the First world too, the gap between the top executives with their millions and people living on social security benefits is becoming grotesque..$^{22}$

One cannot just overlook the sentiments of Moltmann in respect of the decline in the economic and social order of the masses. The fight for jobs, earnings and profits is meant to mobilize the general public's energies. Everyone is the symbol of himself, and unity is left behind. Culture is split into winners and losers in modern societies, the winner takes all and the devil takes the losers. The overwhelming fear of not doing so leads to limitless greed for money and insatiable hunger for food. ${ }^{23}$

\section{MOLTMANN'S THEOLOGY OF HOPE AND THE GHANAIAN CONTEXT}

For Moltmann there has never been so much misery and so much mass death in poorer societies as there is today in the countries of the Third World. This is how he further comments;

We are not only living in class societies. We are living in "two-thirds societies" as well. That means societies in which twothirds of the population is pushing the other third down below the poverty line and degrading them into "surplus people", although the means are available for providing every member of society with a life in freedom and justice. The sufferers are children, old people, the handicapped, the untrained, and many of the minorities. ${ }^{24}$

The above lamentations by Moltmann best describes the Ghanaian situation; the high levels of youth and graduate unemployment, the 'winner takes all' mentality in the social, economic and political life has contributed to as Moltmann describes it, 'boundless greed for life and an insatiable hunger for power.' The attendant negative repercussion as Moltmann describes it is the almost unending and impossible battle against corruption in Ghana. Moltmann does not propose that Modernity is all about negativity. He believes in the many positive things that modern trends in culture, education, technology, trade, economics and globalization can bring. However for him, humanity must be the beneficiary of the good things that modern developmental agenda must bring to bear on the people. The 'craze' for development must not be at the detriment of the masses. Moltmann reiterates the point that, unless modern society prepares for the

\footnotetext{
Kwame Gyekye, Philosophy, Culture and Vision: African Perspectives, (Accra: Sub-Saharan Publishers, 2013), 29

9 Ibid., 19.

Jurgen Moltmann, Faith and the Future; Essays on Theology, Solidarity and Modernity,(Maryknoll: Orbis Books, 1995), 165

Moltmann, Ethics of Hope, 45.

Ibid., 47.

Ibid., 48

Metz and Moltmann, Faith and the Future, 169.
} 
transformation it requires in order to reduce the risk of modernity, the world cannot fulfill its potentialities. The need for a reform in every human society according to Moltmann must take the course of historical vision, the vision of a future worth living for. The appeal of Moltmann for a historical vision is in the fact that for him, true conversion is achieved in history and in forward-looking (vision and hope), and reform can accompany conversion so that the future can be hoped for in new possibilities. Forrester shares the same view with Moltmann when he says;

Hope is a way of envisioning the future. Theology's concern with vision and with hope reminds us that it does not deal only with particular problems and policies and ethical conundrums, any more than it is concerned with the past or with the present. It is at least concerned with the vision that provides the horizon of meaning within which a society exists, policies are formulated, and actions are taken. ${ }^{25}$

The proposal to remedy the contradictions in the phenomenon of modernity is what Moltmann has lived for that is, the journey from political theology to public theology as there is a need to reflect on what the road must be for the Christian faith to participate in the deep things of the socio-political life of people. For if the church has nothing to say or do about the deteriorating social order and political life then nihilism is bound to rule the world of Humans.

\section{MOLTMANN'S POLITICAL THEOLOGY OF HOPE AND PUBLIC THEOLOGY IN GHANA}

The only reality that people would identify the church or Christianity with in terms of its relevance to the socio-cultural life of the people could be in the area of the building of schools, hospitals and other social amenities that the church has been involved in. It is significant to note that in the religious community or Christianity in particular, the expectation of the people is for the church to reoccupy itself with evangelical and spiritual activities of the people. Getting involved in the critical issues of the public and political activities was never the preserve of the church or its doctrine or theology. In secular societies, faith is considered as a private affair and so must not get entangled with issues of public debate. In a secular, (like in the case of Ghana) multicultural, and also multi-ethnic society, it is no longer religious institutions that are central to a society's understanding of itself. However, it is the state that plays this role and the state often feels no need or desire for any sort of grounding in religious faith or some divine order. ${ }^{26}$ However though Ghana is said to be a secular society, it is phenomenal to realize that Ghana is profoundly religious. The religious community has been described as a sacred private entity that must concentrate on their preaching and prayers for the nation and leave the running of the state to the politicians.

This section of the study examines some of the critical challenges to the awakening of the Christian church in Ghana to the importance of "Public Theology" to the wider socio-cultural public and the political system and also most significantly the Christian community. Reflections of Moltmann in respect of the many theological and philosophical considerations given to the concept of "Public Theology" in other jurisdictions will be used as a point of contact.

In other words, the analysis put forward by Moltmann in the development of the conceptual differences of political theology and public theology can help people understand the complexities of attempting public theology in the modern secular, profusely 'politicized' social, religious, and multi-ethnic Ghana which has been influenced by the independence struggle activities as part of the history. There will not be enough time and space to evaluate the history of Ghana in terms of how the desire for freedom and the state ruler-ship by the people brought into being the phenomenon of 'messianism' in its body politic following the example of Jewish and Christian messianic thoughts.

Moltmann has intimated that, "everywhere Christian 'messianism' becomes the dominating philosophical and political idea in the view of history, the people hail them as their messiah in history." ${ }^{27}$ Those who have taken the center stage in the independence and revolutionary struggles have been described as the messiahs Nkrumah never dies' (Kwame Nkrumah-1957-1966); 'Jerry Rawlings as Junior Jesus' (1981-2000).

Human history has mostly been influenced by the religious history of a people and how they view their future in terms of the faith and the culture nuances. The perspective of Moltmann on the development of political theology (which he inadvertently refers to it as his social ethics) is not to be viewed outside the history and development of a particular people. For him, history is not just the recitation of chronology or enumerating of events, but constitutive and appreciative of the total development of a people in the areas of culture, religion, ethnicity and language development, economics and trade, chieftaincy and politics and the preservation of the ecosystem. In the totality of all that, Moltmann asserts that theology must engage civil society together with the history of God's coming Kingdom through Christ's event or eschatological future. ${ }^{28}$

The concept of political theology was mooted by Moltmann after the holocaust (Auschwitz) inflicted on the Jewish community in Germany during the time of Adolf Hitler. ${ }^{29}$ Moltmann's response to the Jews ' atrocities was that

25 Forrester, The Scope of Public theology, 14.

26 Robert Charles Kelly, 'Public Theology and the Modern Social Imagery', Journal of Theology, Vol. 50, Ontario: Wiley Periodicals, 2011.

27 Moltmann, Theology of Hope, 262.

28 Ibid., 264.

29 Jurgen Moltmann, Creating A Just Future: The Politics of Peace and the Ethics of Creation in a Threatened World (London: SCM Press, 1989$)$, 24-25. 
of a people's political and moral crisis in whose name the Jews were given the atrocities. He also saw it as a spiritual crisis of the Christian community in Germany that was deaf whilst they watched or looked away as well as closed their eyes as victims were brought to mass murder alone and forsaken. ${ }^{30}$ The question Moltmann puts into perspective was why the church should remain silent as such a holocaust continued. In this regard, the framework was a redefinition of the church's social and political functions amid the changing modernization trends. ${ }^{31}$ Moltmann's stand in the concept of political theology debunks the assertion from secularists (liberalists) democratic societies that theology in the sense of thoughtful, critical reflection on questions of faith has no public relevance. He therefore makes a critical call on all Christians (Catholics and Protestants or Pentecostals/Charismatics) to participate collaboratively in a theological enterprise that relates critically to society. For Moltmann the concept of political theology has a transconfessional character and ecumenical nature insofar as both Catholics and Protestants stand before the same problem of the growing irrelevance of their doctrines for modern life. ${ }^{32}$

\section{Two perspectival motifs for the political theology framework}

Firstly, it is a call for reflective consciousness whereby political theology takes up functional criticism of social, political and psychological functions of religion or the church. Religious faith or Christian doctrine must be tested for its liberative praxis or oppressive negativities, whether it is alienating or humanizing. It creates the platform according to Moltmann for the church to realize critically its political existence and actual social functions. Moltmann does not invite critical minds just for theology to make politics its central focus, but raises theological questions that would further question the political functions of society. Moltmann is conscious of the fact that, in the praxis of political theology; "It doesn't want the church to be politicized, so it wants to Christianize church politics and Christians ' political involvement. It thus takes up the modern functional critique of religion and urges movement from the orthodoxy of faith to the orthopraxis of Christ's discipleship." 33

Secondly, it is a criticism of the Church and social revolution. Modernity has been part of the developments in human history. Some of modernity's historical developments have been disenchanted by theological extrapolations because of its origin from the $18^{\text {th }}$ century Enlightenment 'religion of reason. ${ }^{34}$ Modernity's consciousness or its Enlightenment consciousness has been viewed by theologians as having the potent force to defect the world from God. Theologians saw it as the image of the Antichrist. To Moltmann modernity has the critical purpose of criticizing, "the past and the traditions regarding origins because it is oriented toward the future and wants to organize human life for the project of making history look better." ${ }^{35}$ Moltmann does not condemn modernity in its entirety, but sees it as having an eschatological significance in modern consciousness because for him the criticism of the past and its origins is oriented toward producing possibilities for the future. Modernity in its positivity has the tendency to what Moltmann refers to as "accounting to the people for the hope that is in us." It provides a wider spectrum for 'a new eschatological orientation of the whole of Christian theology in order that theology can respond with the Biblical promissory history to the modern interest in the history of the future." 36

Several readers of Moltmann have observed the complex nature of his attitude toward issues of modernity to which liberal democratic principles arise. On one hand he has been and remains quite critical of modern social and economic forms of life, seeing them as dehumanizing and alienating both from God and other human beings. ${ }^{37}$ On the other he is a strong supporter of liberal democratic forms of governance structures and pluralistic model of social life. Forrester reiterates that what Moltmann has not addressed in his theology is the necessity for a well-developed model of society from which critique and affirmation might arise. ${ }^{38}$

Moltmann does not share the view that if life in a modern liberal society is amok and things seem to go bad in modern societies, Christian theology should condemn modernity in itself. Individualism and instrumentalization of modernity for Moltmann could be addressed with new modern socialization patterns through the theoretical reengagement of Christian theology. He draws his timeless view of how theology should address problems of civil society consistently for the good of the broader society as a whole. ${ }^{39}$

The concepts of political theology and the later idea of public theology are all from Moltmann's point of view geared toward providing a theological grounding for the reformation that must take place in the interaction between

30 Ibid, 25

31 Jurgen Moltmann, On Human Dignity: Political Theology and Ethics, (Minneapolis: Fortress Press, Ex libris Pub. 2007$), 98$.

32 Ibid.

33 Ibid., 99.

34 Edmund A. Optiz, Religion and Capitalism: Allies and Not Enemies, (New York: The foundation For Economic Education, Irvington-on-Hudson, 1992$)$, 134.

35 Moltmann, On Human Dignity, 99.

36 Moltmann, On Human Dignity, 100.

37 Jurgen Moltmann, God for a Secular Society (Philadelphia: Fortress Press, 1999), 71-75.

38 Forrester, The Scope of Public Theology, 38.

39 Moltmann, God for a Secular society, 17-18. 
Christian theology and civil society. Forrester observes that there is a continuity and consistency that runs throughout Moltmann's approach to issues of Christianity and social concerns, whether referred to as "political" of "public" theology. ${ }^{40}$ So when Moltmann uses the term "political" he means the same as public; inadvertently looking at a broader spectrum of issues to do with socio-culture, politico-economic and eco-culture within the frameworks of social theories and optimistic utopian hope in theology for human society. This has been captured in his "political hermeneutic of theology" ${ }^{41}$ This hermeneutic can therefore be called a political hermeneutic because it apprehends politics, in the Aristotelian sense of the word, as the inclusive horizon of the life of mankind. So political in this sense is to mean all aspects of human life, including not in the narrower sense of the political state of affairs, but also the overall sphere of economy, civil society, religion and family life.

In all of the above, there is one ultimate reality that Moltmann seeks to establish in his public theological discourses and that is the established rule of the Christ in human history. For him, "the whole world is already in Christ and subject to his rule, for God has raised him, exalted him and given him all power in heaven and on earth. Death has already been swallowed up in the victory of the living God." ${ }^{42}$ Human history for Moltmann cannot be complete without reenacting the Christian faith in Christ which is in the light of the resurrection and live in the certainty of Christ's victory. Moltmann refers to this reality of Christian theology reaching out to the public life of the world as Christological eschatology'. This is to mean as he puts it; "God's struggle against Satan, which continues to the end, now becomes the victory of God has attained once and for all in Christ over sin, death and the devil. The eschatological future can only be universal and manifested epiphany of that which in Christ is already 'finished.' ${ }^{43}$ This stand of Moltmann might be seen as a utopia of the rule of Christ in human affairs, but he contends that 'end of utopia, 'end of human history'. For he reiterates, a realistic responsible utopia rather than no hope at all in human history in the reign of God (regnum Dei) in human affairs can be realized.

Of the critical opposition to Moltmann in this project of public theology which has been observed as being optimistically utopianism. Moltmann reiterates his view that, so long as all human beings are born free as agreed by the 1948 International Declaration of Human Rights, ${ }^{44}$ any post-war situation, revolution or local-post-conflict-situation as in the case of Africa and Ghana falls outside this utopia. The task will be equality in the form of social and economic justice, in and between the societies on this earth..$^{45}$

So, for Moltmann, those who are the subjects of the vision of a free and just life are the oppressed people and the hungry masses. There will also be utopian attempts to tackle shame and oppression as long as these occur. There is also hope for a future different from the present sufferings as long as there is such misery. Hope is the life force of the survivors of the world's current structures. Since they are unable to have a fair share of the present, they are looking for an alternative future. ${ }^{46}$

\section{THE WANNING ECUMENICAL SOCIAL ETHICS}

Edmund A. Optiz stresses that the hallmark aspect of modernity is the pursuit of individualism and personal interests that overpower the goodness of society. This means that individual autonomy is always the people's priority even in the broader society. ${ }^{47}$

Such a view has also been observed by Smit in this statement; "Widely accepted popular opinion holds that modern societies often lack meaningful experiences of community, of solidarity, of fellowship, support and care" 48

Since Africa has joined the slogan "global village", the spirit of community deeply embedded in the African reality of social cohesion has been negatively affected with individuality rather than communality. The challenge for the Christian community is the crisis of unity in the one spirit of the Christ who sacrificed for the salvation of humankind and who prayed that 'they may be one as we are one' (John:17). Smit believes that unity in the body of Christ (The Church) transcending all forms of traditions could help the church's dream of effectively getting involved in the social and political realities of the people, those that dehumanize them in particular.

In the particular reference to the South African experience of apartheid and the fight against the regime, Smit has noted that, the unity was in the then Dutch Reformed Mission Church which drafted a confession of faith, rejecting the theology of apartheid in the light of its own understanding of the Christian Gospel. ${ }^{49}$ This confession according to

\footnotetext{
Forrester, The Scope of Public Theology, 39.

Moltmann, On Human Dignity, 105-106.

Moltmann, Ethics of Hope, 20.

Ibid., 21.

United Nations, Universal Declaration of Human Rights, Illustrated Edition (UNRIC/OHCHR, 2015).

Metz and Moltmann, Faith and the Future, 202.

Ibid., 202

Edmund A. Optiz, Religion and Capitalism: Allies and Not Enemies, 134.

8 Dirk Smit, Essays in Public Theology, (Stellenbosch: Sun Press, 2007), 268.

Ibid, 270
} 
Smit was based on the convictions of the Christian community to the effect that, God is praised as the One who gives the Church peace and calls the Church to practice unity; as the One who reconciles the faithful with God himself and with each other and calls them to practice this reconciliation; as the One who is in a special way the God of the poor, the downtrodden and the oppressed and calls the Church to follow him in this. ${ }^{50}$ In the spirit of 'Living Unity' made possible by the unification of Reformed churches in South Africa, the dehumanizing apartheid, has helped to 'annihilate' the common enemy, stressed Smit. ${ }^{51}$

In the case of Ghana, there is diversity in the confessions of unity according to traditions and doctrines common to the various confessions of faith. There is the Christian Council of Ghana, the mother and the foremost ecumenical organization. There are also the Charismatic and the Pentecostal Council of Ghana, the Catholic Secretariat, always represented by the Catholic Bishops' Council and some other 'independent brotherhoods' who do not find their relationship in any of the above uniting church communions.

Moltmann has a response to the contemporary Christian community and the need for rejuvenating the ecumenical spirit of the $21^{\text {st }}$ century church in order to effectively participate as he contends the future of God in Christ on the earth. He has confessed that the nearer the members of various churches come to Jesus Christ the nearer they come to each other. Moltmann made this statement when he made a presentation at the Ecumenical reflections in Geneva at the World Council of Churches on January 13, 2016. He bemoaned the aged-old tendency of theologians making reference to theological reflections from people who belong to their traditions because it is common for Catholic theologians to quote Catholic theologians and for Protestant theologians to quote their like. ${ }^{52}$

Moltmann further reiterated that, although there is a need to feel closer to one's own traditions than to Christianity as a whole ... believers in many parts of the world today are hated and persecuted not because they are Methodists or Reformed, but because they are Christians. For Moltmann the witness of the martyrs is to the One Church of Jesus Christ. He further probes that ultimate confidence must not be placed in the institutional churches as they are seen today, but as he puts it; 'the vision and hope of the ecumenical movement is not in the church, but in the Kingdom of God, and that the church must open up for the surprises of the future. In effect, Moltmann believes that, new and emerging forms of ecclesial constitution and composition are the order of the day, and so the new spirituality must be harnessed. Moltmann reiterates that one needs a modern spirituality of one's senses, promoting a spirituality that takes the environment seriously, moving towards a dedication to what he describes as earth religion. The Ethics of Hope briefly discussed critical issues concerning the harm to Mother Earth and the call for a new spirituality in the face of the world's ecological crisis. ${ }^{53} \mathrm{~A}$ critical review will be done in further research into the need for a renewed spirituality towards ecological ethics of the mother earth.

\section{CONCLUSION}

This article has established the theological focus of Moltmann and how relevant his concept of political/public theology is to be the focus of the Christian community. For Moltmann, human history and development have all expressed the deep sense of humanity's desire to move beyond the reality of today, but to have hope for a better future, a potentiality for change in a positive direction. In analyzing his idea of human hope as a reality in human history, Moltmann believes that the reality of God's future cannot be taken out of the equation. He emphasizes that Christian theology has a role to play in reconnecting all human responsibilities towards God and his created order. In his Ethics of Hope, the point is succinctly made to the effect that, "the Christian ethics of hope is called to life through the recollection of the raising of the crucified Christ and therefore expects the dawn of God's new world in the passing away of old one." 54

All that this article is trying to put across in dialogue with Jurgen Moltmann is that, public (political) theology is not simply a description of the social function of the church in a pluralistic democracy, but Christians are called in practice to represent the law of God in their lives. It is public because it recognizes God's supremacy over every position and operation of humans and knows no corner of human affairs where God is not involved in bringing about his reign. Thus, it is this understanding of the intersection between "public" and "theology" that can provide good grounds for a social understanding and a social ethic that is a true theology of hope. ${ }^{55}$

So, looking forward, perceiving possibilities and anticipating the future of the eschatological Christ in the history and the development of all human races are the fundamental concepts of an ethics of hope. The expectation is that, Christian experience and faith exploits must also gear towards developing the linkage between faith and the many social issues that present critical areas for the consideration of Christian theology in its wider sense. 


\section{ABOUT AUTHORS}

Very Rev. Fr. Dr. Francis Appiah-Kubi, Senior Lecturer at the Kwame Nkrumah University of Science and Technology, Kumasi, Ghana, former Head of the Department of the Religious Studies Department at the Faculty of Social Science in the KNUST is currently Chairman of Tender Evaluation Panel (Goods and Services-Procurement). He is a Ghanaian Theologian specialized in Ecclesiology and studies in African Traditional Religions.

Rev. Dr. Isaac Osei Karkari is an Ordained Minister of the Methodist Church Ghana, Kumasi diocese, in Ashanti Region. He obtained a Bachelor of Divinity degree and Master of Theology in 2007 and 2013 respectively from the Trinity Theological Seminary, Legon, Accra. He recently completed his $\mathrm{PhD}$ at the Department of Religious studies at the Kwame Nkrumah University of Science and Technology, Kumasi with a PhD Thesis on "the Praxis of Public Theology in the perspective of the Theological Method of Jürgen Moltmann in the 21st Century Post-secular African society". His special research areas include ecclesiology and ethical issues facing Christian theology in the African context

\section{BIBLIOGRAPHY}

Asante, Emmanuel. Theology and Society in Context. Accra: Sonlife, 2014.

Bauckham, Richard. The Theology of Jurgen Moltmann. Edinburgh: T \&T Clark, 1999.

Bevans, Stephen B. Models of Contextual Theology. Maryknoll: Orbis Books, 2002.

Casanova, Jose. Public Religions in a Modern World, Chicago: University of Chicago Press, 1994.

Forrester, Duncan. The Scope of Public theology. New York: The Continuum Publishing Group, 2004.

Gyekye, Kwame. Philosophy, Culture and Vision: African Perspectives. Accra: Sub-Saharan Publishers, 2013.

Kelly, Robert Charles. 'Public Theology and the Modern Social Imagery' in A Journal of Theology, Vol. 50, Ontario: Wiley Periodicals, 2011.

Metz, Johann-Baptist and Moltmann, Jurgen. Faith and the Future. Maryknoll, Orbis, 1995, p. 167

Moltmann, Jurgen. Theology of Hope, On the Ground and Implications of a Christian Eschatology. New York: Harper and Row, 1967. Creating A Just Future: The Politics of Peace and the Ethics of Creation in a Threatened World. London: SCM Press, 1989. God for a Secular Society, Philadelphia: Fortress Press, 1999.

Moltmann, Jurgen. Faith and the Future; Essays on Theology, Solidarity and Modernity, Maryknoll: Orbis Books, 1995. Experiences in Theology. Philadelphia: Fortress Press, 2000. On Human Dignity: Political Theology and Ethics. Minneapolis: Fortress Press, Ex-libris Pub 2007. Ethics of Hope. Minneapolis: Fortress Press, 2012.

Optiz, Edmund A. Religion and Capitalism: Allies and Not Enemies, New York: The foundation For Economic Education, Irvington-on-Hudson, 1992.

Smit, Dirk (ed). Essays in Public Theology, Stellenbosch: Sun Press, 2007.

Taiwo, Olufemi. 'Africa and her Challenge of Modernity', Visiting Professor of Philosophy, University of West Indies, Mona Campus, Kingston, Jamaica and Department of Philosophy, Seattle University, Seattle U. S. A., September, 2009. 